\title{
POOL OF BOVINE MORPHOGENETIC PROTEINS AND GUIDED TISSUE REGENERATION IN THE TREATMENT OF INTRABONY PERIODONTAL DEFECTS. I- CLINICAL MEASUREMENTS
}

\author{
“POOL" DE PROTEÍNAS MORFOGENÉTICAS BOVINAS NO TRATAMENTO \\ DE DEFEITOS PERIODONTAIS INTRA-ÓSSEOS. I- MEDIDAS CLÍNICAS
}

\author{
Maria do Carmo Machado GUIMARÃES, DDS, MS \\ Post-graduation student, Department of Prosthodontics and Periodontics, Bauru Dental School, University of Sao Paulo, USP, Brazil. \\ Euloir PASSANEZI, DDS, PhD \\ Professor, Department of Prosthodontics and Periodontics, Bauru Dental School, University of Sao Paulo, USP, Brazil. \\ Adriana Campos Passanezi SANT'ANA, DDS, PhD \\ Professor, Department of Prosthodontics and Periodontics, Bauru Dental School, University of Sao Paulo, USP, Brazil. \\ Sebastião Luiz Aguiar GREGHI, DDS, PhD \\ Professor, Department of Prosthodontics and Periodontics, Bauru Dental School, University of Sao Paulo, USP, Brazil.
}

\begin{abstract}
$T$ he purpose of this study was to evaluate the effect of the pool of bovine BMPs on the treatment of intrabony defects. The sample comprised 15 patients aged 26 to 57 years old presenting with 10 pairs of lesions of 2 or 3 walls or 2-3 walls $35 \mathrm{~mm}$, located in the same type teeth (premolar or molar) and same jaw. The test defects were treated with combination of a pool of bovine bone morphogenetic and resorbable hydroxyapatite carrier (BMPs- HA), bovine demineralized bone matrix (MB) and coverage by a bovine collagen barrier membrane. The control defects were treated with MB-HA and covered by a bovine collagen membrane. The clinical measurements at six months after therapy in the test group revealed a reduction in the mean probing pocket depth (PPD) of $1.63 \pm 1.41 \mathrm{~mm}$ (B) and $1.93 \pm 0.96 \mathrm{~mm}(\mathrm{~L})$ and a mean change in the clinical attachment level (CAL) of $1.60 \pm 1.16 \mathrm{~mm}(\mathrm{~B})$ and $1.46 \pm 0.97 \mathrm{~mm}$ (L). The control group showed a mean reduction of PPD of $1.93 \pm 1.34 \mathrm{~mm}(\mathrm{~B})$ and $2.0 \pm 1.51 \mathrm{~mm}(\mathrm{~L})$ and a mean change of CAL of $1.03 \pm 1.24 \mathrm{~mm}(\mathrm{~B})$ and $1.30 \pm 1.14 \mathrm{~mm}(\mathrm{~L})$. The analysis of variance (ANOVA) demonstrated that the changes in the clinical parameters were statistically significant $(\mathrm{p}<0.05)$. There were no significant differences between the test and controls subjects (Student's test, $\mathrm{p}<0.005$ ). These findings suggest that the use of a pool of bovine BMPs do not provide added effects to GTR in the treatment of intrabony defects.
\end{abstract}

UNITERMS: Periodontal regeneration; Intrabony defects; Bone morphogenetic proteins.

\section{INTRODUCTION}

According to the principle of Guided Tissue Regeneration (GTR), use of the barrier membrane ${ }^{15}$ aims at guiding and mechanically controlling the tissue regeneration by preventing the adjacent epithelial and gingival connective tissues from accessing the prepared root surfaces during the healing process. This provides a selective re-population of the root surface and surrounding spaces by the periodontal ligament and alveolar bone cells. However, the results are not totally predictable, even though preclinical studies in animal models and clinical studies have demonstrated the possibility of an effective increase in periodontal regeneration by the GTR.

On the other hand, improvements in molecular and cellular biology have been allowing a better comprehension of the functions of the growth factors and their interaction with the extracellular matrix and the cells during the healing process. A new alternative to the treatment of bone defects came from the findings of Urist ${ }^{27}$ and Reddi; Huggins ${ }^{17}$, who 
demonstrated that the devitalized and demineralized bone matrix is able to induce heterotopic osteogenesis. The bone morphogenetic proteins (BMPs), present in the interior of bone matrix, display osteogenic and osteoinductive properties that, when released, induce the sequential process of formation of new bone tissue.

In addition, many microscopic studies have supported the premise that the BMPs provide regeneration of the tooth supporting apparatus, including the cementum, periodontal ligament and alveolar bone 2,6, 9, 10,11,18,19,21,22.

The difficulty to obtain enough amounts of viable human bone, associated with the costs and risks of transmission of pathological entities, many studies have been applying bovine bone matrix for the treatment of intrabony defects. This utilization is based on the homology proved by cloning of DNA of human BMPs with bovine bone. However, the commercially-prepared demineralized bone powder (DFDBA) presents an insufficient quantity of BMPs to induce differentiation of mesenchymal cells in enough numbers of osteoprogenitor cells to yield a clinically significant bone neoformation ${ }^{1}$.

In this study, application of the pool of bovine BMPs (GENPRO $^{\mathrm{TM}}$ - Baumer S.A.), developed from the lyophilized bovine bone matrix, was evaluated. In a previous study, this biomaterial demonstrated favorable results regarding the structural biocompatibility, and induced bone regeneration in perennial skull defects in Guinea pigs ${ }^{24}$ when associated with the bone matrix.

The pool just contains the BMP extract, since the proteins concentrate the osteogenic potential generically attributed to the matrix. Compared to other biomaterials, which use the whole matrix, this extract gathers greater quantities as well as different types of those proteins and therefore is named pool of BMPs.

This work associated application of the collagen resorbable membrane Type I (GENDERME ${ }^{\mathrm{TM}}$ - Baumer S.A.), obtained from the bovine cortical bone ${ }^{7,23}$ and the pool of bovine BMPs in the periodontal regenerative therapy, in an attempt to evaluate the clinical results of the combination of those regenerative modalities.

\section{MATERIALSAND METHODS}

Fifteen patients of both genders (aged 26 to 57 years old with a mean age of 36.06 years) were selected at the Periodontics clinic of Bauru Dental School, University of Sao Paulo, SP, Brazil. The possible types of treatment, associated risks and benefits were explained to the patients, all of whom signed and informed consent form agreeing to the treatment. The study design and the consent term were approved by the Ethics Committee of Bauru Dental School.

The inclusion criteria comprised the following: 1) good systemic health; 2) no use of drugs such as antibiotics, corticoids, chemotherapeutics, or immunological modulators that might alter the response of the oral tissue; 3) nonsmokers; 4) radiographic evidence of at least one pair of interproximal intrabony defects with 2 or 3 or combined 2-3 walls located in the same jaw (maxilla or mandible) and the same type of tooth (premolars or molars), without involvement of the furcations; vital or root canal treated teeth; attachment level ${ }^{35} \mathrm{~mm}$; tooth mobility < class II.

The exclusion criteria comprised patients with reported allergy to bovine products, tetracycline, chlorhexidine, history of anaphylactic reactions and state of pregnancy or alcoholism.

After selection, all patients underwent the initial therapy consisting of oral hygiene instruction, scaling and root planning and necessary occlusal adjustment.

Reevaluation was performed six weeks after phase I therapy to confirm the suitability for this periodontal surgery study. The following clinical parameters were assessed at the reevaluation and regarded as baseline values: Plaque Index $^{14}$, Gingival Index ${ }^{14}$, probing pocket depth (PPD), gingival recession (GR) and clinical attachment level (CAL). The measurements were made at 6 sites per tooth (mesiobuccal, midbuccal, distobuccal, mesiolingual, midlingual, and distolingual). The PPD and CAL were repeated within a week with a millimeter periodontal probe "Michigan 0" type with Willians (Hu-Friedy -USA) markings. Individualized film holders were used for the achievement of standardized radiographs.

At least six weeks after conclusion of the initial periodontal therapy, the sample was submitted to the surgical phase using the split-mouth design, on which 2 interproximal sites were randomly assigned to the experimental or control groups.

After extra and intraoral asepsis of the surgical field, full-thickness mucoperiosteal flaps were raised by means of buccal and lingual intracrevicular incisions until at least one mesial and one distal adjacent teeth, followed by removal of the granulation tissue and bone debridement with Goldman Fox curettes \#1, 2, 3 and 4 (HU-FRIEDY USA). After that, a $50 \%$ citric acid solution, $\mathrm{pH} 1.0$ with $10 \%$ tetracycline solution was applied over the root surface and bone defects for three minutes, followed by rinsing with sterile saline solution for one minute.

Subsequently, a pool of bone morphogenetic proteins (GENPRO $^{\mathrm{TM}}$, Baumer S.A) obtained from the bovine bone matrix of bovine fetus with resorbable hydroxyapatite carrier (HA) (BMP HA at 1:20 ratio), with addition of demineralized lyophilized bovine bone matrix (MB) (MO-GEN-OX ${ }^{\mathrm{TM}}$, Baumer S.A) at 1:1 ratio in sterile saline solution was applied on the test defects. The mixture was condensed in the defects and filled with little excess in order to provide support to the barrier.

In the control sites there was application of MB with HA (MB-HA), at 1:1 ratio, therefore excluding just the pool of bovine BMPs.

After filling the defects with the respective biomaterials, both the test and control sites were covered with a $160-\mathrm{mm}$ thick resorbable membrane obtained from bovine cortical bone (GENDERME ${ }^{\mathrm{TM}}$, Baumer S.A). The bioresorbable membrane was trimmed and adjusted over the whole defect so that the entire defect and $3 \mathrm{~mm}$ of alveolar bone were completely covered. The flap was repositioned at the height 
of the cementoenamel junction, adapted over the membrane and sutured with Vicryl 6.0 suture and 1.50 1/2 J105 G (ETHICON) needle.

The postoperative instructions included prescription of $100 \mathrm{mg}$ of oral doxycycline once a day for fourteen days and rinsing with $0.12 \%$ chlorhexidine digluconate solution twice a day for six weeks. In addition, the patients received orientations on other postoperative cares, adequate use of dental floss and delicate brushing of the operated area during the first postoperative weeks.

At three and six months after surgery, new clinical measurements were undertaken, and new standardized radiographs were obtained at six months.

Analysis of the means of PPD and CAL was performed by means of analysis of variance (ANOVA), at $p<0.05$, in order to indicate differences between the initial, 3-month and 6-month measurements of each group. Whenever significant differences were found, the Tukey test was applied to indicate in which periods the differences were significant. The Student's t test $(\mathrm{p}<0.05)$ was applied to indicate whether the variations in PPD and CAL in the initial, 3-month and 6-monthj periods presented statistically significant differences between the test and control groups.

\section{RESULTS}

According to Table 3, the variation in the probing depth on the $\mathrm{B}$ and $\mathrm{L}$ aspects, between the measurements at the initial, 3-month and 6-month periods did not present statistically significant differences between the test and control groups.

According to Table 7 , the variation in the clinical attachment level in the measurements at the initial (MI), 3month $(3 \mathrm{~m})$ and 6-month $(6 \mathrm{~m})$ periods did not present statistically significant differences between the test and control groups.

In Table 8, the analysis of variance showed a significant difference $(\mathrm{p}<0.05)$ between the evaluation periods regarding the mean CAL on the buccal and lingual aspects of the test and control groups, respectively. The Tukey test (Schedule 9) demonstrated significant differences in the initial measurement compared to the 3-month and 6-month periods.

\section{DISCUSSION}

Periodontal regeneration results in the formation of new bone, new cementum and new periodontal ligament, ${ }^{5}$ and many methods have been proposed to reach this aim. In the present in vivo study, the effects of the utilization of a pool of bovine BMPs associated with demineralized lyophilized bovine bone matrix and bovine collagen membrane in the treatment of periodontal human intrabony defects by means of clinical parameters have been evaluated.

Even though studies on GTR have evidenced formation of new attachment connective tissue, deposition of new cementum, new periodontal ligament and new bone formation in surgically created defects submitted to GTR with resorbable membrane barriers ${ }^{15}$, some studies reported the non-formation of new bone ${ }^{16}$ and detected dense connective tissue instead of alveolar bone ${ }^{8}$ after application of barriers in surgically created defects in animals. In those situations, the clinical repair of bone defects cannot be defined as regeneration, even when there is formation of new attachment connective tissue. For that reason, formation of new tissue with the same structural and functional characteristics of the tissue existing before the destructive disease is not observed ${ }^{5}$.

The resorbable collagen membrane used in this study was obtained from collagen of organic matrix Type I of bovine cortical bone. Studies on animal models revealed good tolerance of the tissues to this biomaterial and complete resorption six months after its placement in orthotopic sites in the surface of perennial skull defects in Guinea pigs ${ }^{23}$.

The association of resorbable membranes in different regenerative modalities has been established in microscopic and clinical studies, which observed different results regarding the periodontal regeneration, improvement of the clinical parameters and bone gains ${ }^{13}$.

Since the commercially-prepared demineralized bone powders present bone matrix with insufficient quantity of $\mathrm{BMPs}^{1}$, therefore not attaining a good regenerative response in the treatment of bone defects, the addition of a pool of BMPs to the bone matrix in this study aimed at assuring the osteogenic activity and the further roles of those proteins in periodontal regeneration. However, the data achieved indicated that the addition of the pool of BMPs did not yield better results.

The BMPs are considerably involved in the healing of surgical wounds, especially in periodontal regeneration, since they initiate formation of new bone tissue by stimulating the differentiation of undifferentiated mesenchymal cells in osteoblasts ${ }^{28}$. The formation of new bone in surgically created defects treated with BMPs has been reported in a microscopic study ${ }^{6}$.

Microscopic studies have showed the formation of new cementum, periodontal ligament and bone neoformation by application of rhBMP-2 $2^{10,11,21,22}$ and other $\mathrm{BMPs}^{6,18,19}$. Nevertheless, Choi et al. ${ }^{3}$ pointed out the non-significant formation of cementum.

The clinical findings of this study demonstrated that the BMPs employed did not being about additional benefits. Similar results have been noticed between the test and control sites regarding the gain of CAL and reduction in PPD.

In the test sites, on which the pool of BMPs has been added, a mean reduction in probing depth of $1.63 \mathrm{~mm}$ (B) and $1.93 \mathrm{~mm}(\mathrm{~L})$ was achieved six months postoperatively. In the control sites, where BMPs were not used, a reduction of $1.93 \mathrm{~mm}$ (B) and 2.0mm (L) was obtained. In Table 3, it can be noticed that the groups did not present statistically significant differences between them regarding the reduction in PPD at six months, even though it was significant in two groups from the initial examination to the six-month analysis 
(Tables 4 and 5). The reduction in PPD according the ANOVA method complemented by the Tukey test was statistically significant $(\mathrm{p}<0.05)$ at 3 -month postoperatively (Tables 4 and 5) in the test and control groups, although there was no statistically significant difference between the results obtained at three and sixth months.

When analyzing the gain of CAL, it is observed that, at six months, the test sites presented a mean gain of $1.60 \mathrm{~mm}$ (B) and $1.46 \mathrm{~mm}(\mathrm{~L})$, while the control sites presented a mean gain of $1.03 \mathrm{~mm}(\mathrm{~B})$ and $1.30 \mathrm{~mm}(\mathrm{~L})$. Those differences were not statistically significant (Table 7). In the same way, the analysis of variance showed that the attachment gain was significant in both groups $(\mathrm{p}<0.05)$ at three months postoperatively, maintaining the lack of significant difference $(\mathrm{p}<0.05)$ at six months postoperatively (Tables 8 and 9).
The gingival recession is a frequent finding after GTR. Nevertheless, it has not been considered significant ${ }^{29}$. In this study, the occurrence of a significant recession in the control group compared to the test group did not yield differences between the groups concerning the attachment gain (Table 6).

The presence and quantity of new bone can only be determined by means of studies that accomplished surgical reentrance or microscopic analysis. The filling of intrabony defects by neoformed bone tissue has been verified during a reentrance surgery done at the six months postoperatively in some reports ${ }^{13}$. However, the nature of the neoformed tissue and the occurrence of regeneration can just be defined by microscopic analysis. In the present study, those procedures were not applied for ethical reasons and were

TABLE 1

\begin{tabular}{|c|c|c|c|c|c|c|c|}
\hline \multirow[t]{2}{*}{ Group } & \multicolumn{2}{|c|}{ MI } & \multicolumn{2}{|c|}{$3 m$} & \multicolumn{2}{|c|}{$6 m$} & \multirow[t]{2}{*}{ Friedman (p) } \\
\hline & $x$ & $d p$ & $x$ & $d p$ & $\mathbf{x}$ & $d p$ & \\
\hline Test & 0,766 & 0,359 & 0,616 & 0,471 & 0,660 & 0,645 & 0,266 ns \\
\hline Control & 0,823 & 0,503 & 0,618 & 0,494 & 0,777 & 0,723 & $0,377 \mathrm{~ns}$ \\
\hline Wilcoxon (p) & \multicolumn{2}{|c|}{0,892 ns } & \multicolumn{2}{|c|}{0,715 ns } & \multicolumn{2}{|c|}{$0,398 \mathrm{~ns}$} & \\
\hline
\end{tabular}

ns- Non-significant differences $(P<0.05)$

TABLE 2

\begin{tabular}{|c|c|c|c|c|c|c|c|}
\hline \multirow[t]{2}{*}{ Group } & \multicolumn{2}{|c|}{ MI } & \multicolumn{2}{|c|}{$3 m$} & \multicolumn{2}{|c|}{$6 m$} & \multirow[t]{2}{*}{ Friedman $(p)$} \\
\hline & $\mathbf{x}$ & dp & $x$ & $d p$ & $x$ & $d p$ & \\
\hline Test & $1.829^{a}$ & 0.363 & $1.220^{\mathrm{b}}$ & 0.581 & $1.017^{c}$ & 0.587 & $0.002^{*}$ \\
\hline Control & $1.827^{\mathrm{a}}$ & 0.341 & $1.208^{\mathrm{b}}$ & 0.548 & $1.064^{\mathrm{b}}$ & 0.573 & $0.004^{*}$ \\
\hline
\end{tabular}

* statistically significant difference $\quad(P<0.05)$

Same letters indicate non-significant differences

TABLE 3

\begin{tabular}{|c|c|c|c|c|c|c|}
\hline \multirow[t]{2}{*}{ Variation } & \multirow[t]{2}{*}{ Aspect } & \multicolumn{2}{|c|}{ Test } & \multicolumn{2}{|c|}{ Control } & \multirow[t]{2}{*}{$\mathbf{P}$} \\
\hline & & $x$ & $d p$ & $x$ & $d p$ & \\
\hline \multirow[t]{2}{*}{$3 m-M I$} & B & -1.400 & 1.183 & -2.000 & 1.647 & $0.178 n s$ \\
\hline & $\mathrm{L}$ & -1.533 & 1.125 & -1.733 & 1.449 & $0.657 \mathrm{~ns}$ \\
\hline \multirow[t]{2}{*}{ 6m-MI } & B & -1.633 & 1.141 & -1.933 & 1.347 & $0.443 \mathrm{~ns}$ \\
\hline & $\mathrm{L}$ & -1.933 & 0.961 & -2.000 & 1.511 & $0.886 n s$ \\
\hline \multirow[t]{2}{*}{$6 m-3 m$} & B & -2.333 & 0.863 & 0.066 & 0.728 & $0.340 \mathrm{~ns}$ \\
\hline & $\mathrm{L}$ & -0.400 & 0.910 & -0.266 & 1.083 & $0.657 \mathrm{~ns}$ \\
\hline
\end{tabular}


based on data from the literature for establishment of the evaluation periods employed.

Many factors are well accepted as playing key roles in regenerative procedures: initial depth of the defect, number of walls of the bony defect ${ }^{4}$, careful daily plaque control, adequate control of membrane infection, creation and maintenance of space below the membrane, and smoking ${ }^{25,26}$. The improper control of those factors can be responsible for the differences observed in the results of the studies accomplished.

The level of plaque control performed by the patient has an important influence in regenerative therapy. Better levels of clinical attachment have been observed in patients with better plaque control compared to the patients with poor plaque control ${ }^{26}$.

All patients in this study were instructed on oral hygiene

TABLE4

\begin{tabular}{|c|c|c|c|c|c|c|c|}
\hline & Face & gl & QM Effect & $\begin{array}{l}\text { PPD } \\
\text { gl error }\end{array}$ & QM error & $F$ & $\mathbf{P}$ \\
\hline \multirow[t]{2}{*}{ Teste } & $\mathrm{V}$ & 2 & 11,705 & 28 & 0,574 & 20 & $<0,001^{*}$ \\
\hline & $\mathrm{L}$ & 2 & 15,622 & 28 & 0,503 & 31,047 & $<0,001^{*}$ \\
\hline \multirow[t]{2}{*}{ Controle } & V & 2 & 19,355 & 28 & 0,843 & 22,942 & $<0,001^{*}$ \\
\hline & L & 2 & 17,688 & 28 & 0,772 & 22,906 & $<0,001^{*}$ \\
\hline
\end{tabular}

* significant statistically difference $(p<0,05)$

TABLE 5

\begin{tabular}{|c|c|c|c|c|c|c|c|}
\hline \multirow[t]{2}{*}{ Group } & \multirow[t]{2}{*}{ Face } & \multicolumn{2}{|c|}{ MI } & \multicolumn{2}{|c|}{$3 m$} & \multicolumn{2}{|c|}{$6 m$} \\
\hline & & $x$ & $d p$ & $x$ & $d p$ & $x$ & $d p$ \\
\hline & V & $5,466^{a}$ & 1,060 & $4,066^{b}$ & 0,883 & $3,833^{b}$ & 0,879 \\
\hline \multicolumn{8}{|l|}{ Test } \\
\hline & L & $5,733^{a}$ & 1,162 & $4,200^{b}$ & 1,424 & $3,800^{\mathrm{b}}$ & 1,146 \\
\hline & V & $5,866^{a}$ & 1,597 & $3,866^{b}$ & 1,302 & $3,933^{b}$ & 0,979 \\
\hline \multicolumn{8}{|c|}{ Control } \\
\hline & L & $5,933^{a}$ & 1,449 & $4,200^{b}$ & 1,373 & $3,933^{b}$ & 0,883 \\
\hline
\end{tabular}

Same letter- No significant differences

TABLE 6

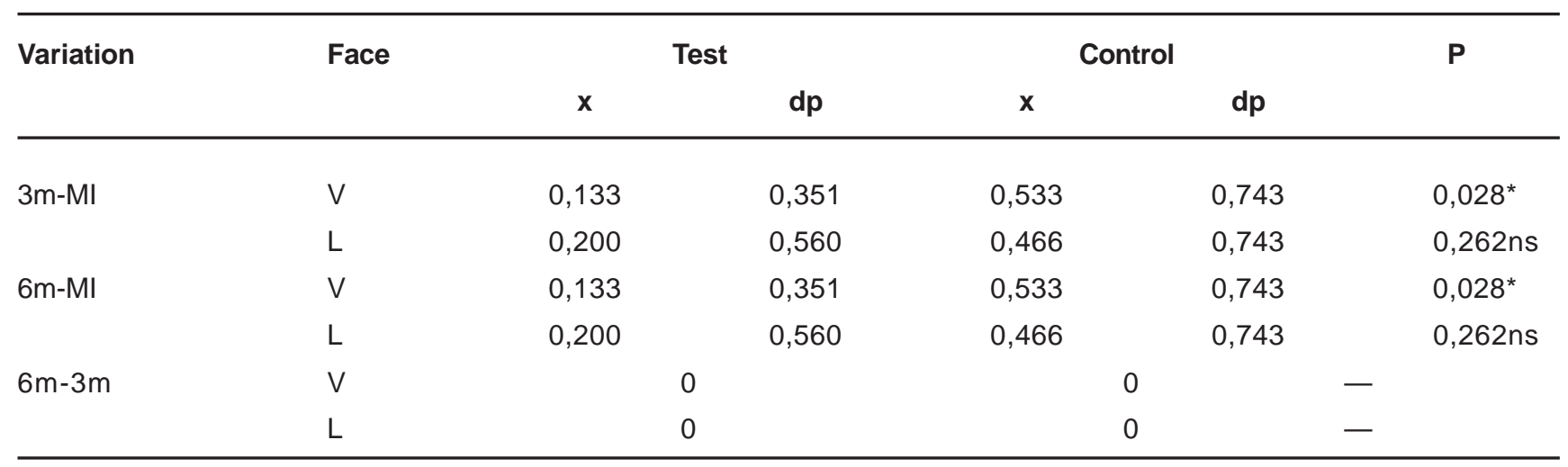

* significant statistically difference $(P<0,05)$; ns No significant differences 
at the first appointment. The test and control groups were standardized and, at initial measurement, a mean PI equal or lower than 1 was obtained in the recording of the entire mouth and specifically in the study sites.

Within the criteria of the methodology of this study, smokers were not included in the sample since they are at a higher risk of exposition of the barrier, have a low healing response, and as a result show a smaller attachment gain and higher tendency to bone loss after regenerative therapy ${ }^{25}$.

In addition, the pairs of defects selected always referred to the same type of tooth (molars and premolars) and located in the same jaw.

The HA carrier associated with the pool of BMPs in this study may have partially interfered with the process of bone formation by the BMPs, since it is present in solid particles.

TABLE7

\begin{tabular}{|c|c|c|c|c|c|c|}
\hline \multirow[t]{2}{*}{ Variation } & \multirow[t]{2}{*}{ Face } & \multicolumn{2}{|c|}{ Test } & \multicolumn{2}{|c|}{ Control } & \multirow[t]{2}{*}{$\mathbf{P}$} \\
\hline & & $x$ & $d p$ & $x$ & $d p$ & \\
\hline \multirow[t]{2}{*}{ 3m-MI } & V & $-1,200$ & 1,014 & $-1,233$ & 1,545 & $0,938 \mathrm{~ns}$ \\
\hline & $L$ & $-1,266$ & 0,883 & $-0,833$ & 1,175 & $0,201 \mathrm{~ns}$ \\
\hline \multirow[t]{2}{*}{$6 \mathrm{~m}-\mathrm{Ml}$} & V & $-1,600$ & 1,168 & $-1,033$ & 1,245 & $0,165 \mathrm{~ns}$ \\
\hline & $L$ & $-1,466$ & 0,972 & $-1,300$ & 1,114 & $0,591 \mathrm{~ns}$ \\
\hline \multirow[t]{2}{*}{$6 m-3 m$} & V & $-0,400$ & 0,890 & 0,200 & 0,840 & $0,091 \mathrm{~ns}$ \\
\hline & $\mathrm{L}$ & $-0,200$ & 0,959 & $-0,466$ & 0,833 & $0,326 n s$ \\
\hline
\end{tabular}

No significant differences $(P<0,05)$

TABLE8

\begin{tabular}{|c|c|c|c|c|c|c|c|}
\hline Group & Face & gl & QM Effect & $\begin{array}{l}\text { PPD } \\
\text { gl error }\end{array}$ & QM error & $F$ & $\mathbf{P}$ \\
\hline & V & 2 & 10,40 & 28 & 0,530 & 19,587 & $<0,001^{*}$ \\
\hline \multicolumn{8}{|l|}{ Test } \\
\hline & $L$ & 2 & 9,488 & 28 & 0,441 & 21,503 & $<0,001^{*}$ \\
\hline & V & 2 & 6,572 & 28 & 0,774 & 8,484 & $0,001 *$ \\
\hline \multicolumn{8}{|l|}{ Control } \\
\hline & $\mathrm{L}$ & 2 & 6,505 & 28 & 0,553 & 11,760 & $<0,001^{*}$ \\
\hline
\end{tabular}

* significant statistically difference $(p<0,05)$

TABLE 9

\begin{tabular}{|c|c|c|c|c|c|c|}
\hline \multirow{3}{*}{ Face } & \multicolumn{6}{|c|}{ CAL } \\
\hline & \multicolumn{2}{|c|}{ MI } & \multicolumn{2}{|c|}{$3 m$} & \multicolumn{2}{|c|}{$6 \mathrm{~m}$} \\
\hline & $\mathbf{x}$ & $d p$ & $x$ & $d p$ & $x$ & $\mathrm{dp}$ \\
\hline V & $5,266^{a}$ & 1,099 & $4,066^{b}$ & 1,162 & $3,666^{b}$ & 1,331 \\
\hline L & $5,400^{a}$ & 1,352 & $4,133^{b}$ & 1,164 & $3,933^{b}$ & 1,321 \\
\hline V & $5,633^{a}$ & 1,099 & $4,400^{b}$ & 1,162 & $4,600^{b}$ & 1,331 \\
\hline L & $5,700^{a}$ & 1,352 & $4,866^{b}$ & 1,164 & $4,400^{b}$ & 1,321 \\
\hline
\end{tabular}

Same letter- No significant differences 
According to Kuboki et al. ${ }^{12}$, the geometrical structure of hydroxyapatite in solid particles does not offer adequate environment for vascularization, partially interfering with the osteogenesis. On the other hand, in HA with porous or coral structure, there is creation of sufficient environment for vascularization.

The tetracycline and citric acid compound employed in this study was developed by the Department of Biochemistry of the Bauru Dental School-USP. Sant'Ana ${ }^{20}$, when treating root fragments in damaged periodontium with this compound, noticed a greater number of adhered cells, the desobliteration of the dentinal tubuli and removal of the smear layer, with achievement of a more regular and "clean" cementum surface, without evidence of remnants of calcified or uncalcified tissue.

The findings of this study suggest that addition of the pool of bovine BMPs in HA carrier to the lyophilized demineralized bone matrix does not result in improvement of the clinical parameters.

On the other hand, the stability and gain of clinical attachment and the reduction in probing depth observed during the treatment effectively resulted in improvement of the clinical conditions in patients treated in both groups, eliminating or at least reducing the existing periodontal pockets.

\section{CONCLUSIONS}

- The addition of a pool of bovine BMPs to the demineralized lyophilized bovine bone matrix (MB) did not present additional clinical benefits in the treatment of intrabony defects;

- The stability, gains in clinical attachment and reduction in probing depth actually yielded an improvement in the clinical conditions for both groups.

\section{RESUMO}

Este estudo teve como objetivo avaliar a aplicação do “pool” de BMPs bovinas no tratamento de defeitos intraósseos. A amostra constou de quinze indivíduos com idade entre 26 e 57 anos, apresentando um par de defeitos intraósseos comparáveis, localizados no mesmo arco em dentes do mesmo tipo (pré-molares ou molares) e com perda de inserção (PI) 35mm. Em cada indivíduo, o defeito teste foi tratado com a associação “pool” de BMPs- carreador Hidroxiapatita reabsorvível (BMPs-HA), matriz orgânica bovina desmineralizada liofilizada (MO) e barreira de colágeno bovino, enquanto os defeitos controle foram tratados com MO-HA e barreira de colágeno. Na avaliação clínica aos seis meses após a medida inicial, o grupo teste apresentou variação de profundidade de sondagem (PS) de $-1,63 m m \pm 1,141$ na vestibular (V) e-1,93mm $\pm 0,961$ na lingual (L) e variação do nível de inserção (NI) de -1,60mm $\pm 1,168$ na V e -1,46mm $\pm 0,972$ na L. O grupo controle apresentou variação de PS de -1,93mm \pm 1,347 (V) e-2,0mm \pm 1,511 (L)e variação de NI de -1,03mm \pm 1,245(V) e -1,30mm \pm 1,114(L). A análise de variância indicou que a variação de PS e NI foi significativa em ambos os grupos $(\mathrm{p}<0,05)$. Entretanto, de acordo com o teste $t$ não houve diferença significativa entre os grupos quanto à variação PS e NI $(\mathrm{p}<0,05)$. Em conclusão, a aplicação do "pool” de BMPs não oferece benefícios adicionais ao tratamento de defeitos intra-ósseos.

UNITERMOS: Regeneração periodontal; Defeitos intraósseos; Proteínas ósseas morfogenéticas.

\section{ACKNOWLEDGEMENTS}

This study was supported by Grant \#98/13005-9 from The State of Sao Paulo Research Foundation (FAPESP)

\section{REFERENCES}

1- Becker W, Becker BE. Periodontal regeneration: a contemporary re-evaluation. Periodontology 20001999 Feb; 19:104-14.

2- Bowers G. Histologic comparison of regeneration in human intrabony defects when Osteogenin is combined with demineralized freeze-dried bone allograft and with purified bovine collagen. J Periodontol 1991 Nov; 62(11):690-702.

3- Choi SH, Kim CK, Cho, KS, Huh, JS, Sorensen, RG, Wosney $\mathrm{JM}$, et al. Effect of recombinant human bone morphogenetic protein-2/absorbable collagen sponge (rhBMP-2/ACS) on healing in 3-wall intrabony defects in dogs. J Periodontol 2002 Jan; 73(1):63-72.

4- Cortellini P, Carnevale G, Sanz M, Tonetti MS. Treatment of deep and shallow intrabony defects. A multicenter randomized controlled clinical trial. J Clin. Periodontol, 1998 Dec; 25(12):9817.

5- Garrett, S. Periodontal regeneration around natural teeth. Ann Periodontol, 1996 Nov; 1(1):621-66.

6- Giannobile WV. Recombinat human osteogenic protein-1 (OP1) stimulates periodontal wound healing in class III furcation defects. J Periodont 1998 Feb; 69 (2):129-37.

7- Herculiani PP, Cestari TM, Taga EM, Taga M. Tratamento de defeito ósseo perene em calvária de cobaia com membrana de cortical óssea bovina liofilizada associada ou não a enxerto ósseo bovino desmineralizado. Rev Bras Implant 2000; 6(2):7-14.

8- Kersten BG, Chamberlain ADH, Khorsandi S, Wikesjö UME, Selvig KA, Nilvéus RE. Healing of the intrabony periodontal lesion following root conditioning with citric acid and wound closure including ePTFE membranes. J Periodontol 1992 Nov; 63(11):876-82.

9- King GN, King N, Hughes FJ. Effect of two delivery systems for recombinant human bone morphogenetic protein-2 on periodontal regeneration in vivo. J Periodontol Res 1998 May; 33(4):226-36. 
10- King GN, King N, Cruchley AT, Wosney JM, Hughes FJ. Recombinant human bone morphogenetic protein-2-promotes wound healing in rat periodontal fenestration defects. J Dent Res 1997 Aug; 76(8):1460-70.

11- Kinosshita A, Oda S, Takahashi K, Yokota S, Ishikawa I. Periodontal regeneration by application of recombinant human bone morphogenetic protein-2 to horizontal circumferential defects created by experimental periodontitis in Beagle dogs. J Periodontol 1997 Feb; 68(2):103-9.

12- Kuboki Y, Takita H, Kobayashi D, Tsuruga E, Inoue M, Murata $\mathrm{M}$ et al. BMP-Induced osteogenesis on the surface of hydroxyaapatite with geometrically feasible and nonfeasible structures: topology of osteogenesis. J Biomed Mater Res 1998 Feb; 39(2):190-8.

13- Lekovic V, Camargo PM, Weinlaender M, Vasilic N Kenney EB. Comparison of platelet-rich plasma, bovine porous bone mineral, and guided tissue regeneration versus plated-rich plasma and bovine porous bone mineral in the treatment of intrabony defects: a reentry study. J Periodontol 2002 Feb; 73(2):198-205.

14- Löe, H. The Gingival Index, the Plaque Index and the Retention Index Systems. J. Periodont. 1967; 38 (sp. Issue):610-6.

15- Nyman S. The regenerative potential of the periodontal ligament. An experimental study in monkey. J Clin. Periodontol 1982 May; 9(3):257-65.

16- Pitaru S, Tal H, Soldinger M, Nof M. Collagen membranes prevent the apical migration of epithelium and support new connective tissue attachment during periodontal wound healing in dogs. J Periodontol Res 1989 Jul; 24(4):247-54.

17- Reddi A, Huggins CB. Biochemical sequences in the transformation of normal fibroblasts in adolescent rats. Proc Natl Acad Sci USA 1972; 69 (6):1601-5.

18- Ripamonti U, Heliotis M, Heever van den B, Reddi AH. Bone morphogenetic proteins induce periodontal regeneration in the baboon (Papio ursinus). J Periodontol 1994 Nov; 29(6):439- 45.

19- Ripamonti U, Heliotis M, Rueger DC, Sampath TK. Induction of cementogenesis by recombinat human osteogenic protein-1 (hOP1/BMP-7) in the baboon (Papio ursinus). Arch Oral Biol 1996 Jan; 41(1):121-6.

20- Sant'Ana, A C P. Efeitos da aplicação de diferentes fatores de crescimento (PDGF-BB, IGF-1 e TGF-b1) isolados ou combinados na taxa de proliferação e na adesão de fibroblastos derivados de ligamento periodontal humano e fragmentos radiculares tratados ou não com ácido cítrico e tetraciclina após a raspagem. Bauru; 2001. [Tese de Doutorado- Faculdade de Odontologia de Bauru da USP].

21- Sasaki M, Kato H, Kuboki Y. A study of periodontal regenerative therapy using bone morphogenetic protein (BMP)treatment of monkey's furcation involvement using collagen membrane as a spacer. J Jpn Soc Periodontol 1996; 38(4):428-46.

22- Sigurdsson TJ, Nygaard L, Tatakis DN, Fu E, Turek TJ, Jin L, et al. Periodontal repair in dogs: evaluation of rhBMP-2 carriers. Int J Periodontol Restorat Dent 1996 Dec; 16(6):524-37.
23- Taga R, Hassunuma CY, Cestari TM, Ferreira PM. Destino de membrana de cortical óssea bovina colocada em posição subperióstica na calvária de cobaia. Rev Bras. Implant 1997; 3(6):24-9.

24- Taga R. Reparo de defeito ósseo perene em crânio de cobaia pela aplicação de osseobond. Rev. Bras. Implant. 1997; 3(1):1320.

25- Tonetti MS, Pini Prato G, Cortellini P. Effect of cigarrete smoking on periodontal healing following GTR in infrabony defects. A preliminary retrospective study. J. clin. Periodont. 1995 Mar; 22(3):229-34.

26- Tonetti MS, Pini Prato G, Cortellini P. Factors affecting the healing response of intrabony defects following guided tissue regeneration and aces flap surgery. J Clin. Periodontol 1996 Jun; 23(6):548-56.

27- Urist MR. Bone: formation by autoinduction. Science 1965; 150:893-9.

28- Zaman KU, Sugaya T, Kato H. Effect of recombinat human plated-derived growth factor-BB and bone morphogenetic protein2 application to demineralized dentin on early periodontal ligament cell response. J Periodontal Res 1999 Jul; 34(5):244-50.

29- Zybutz MD, Laurel L, Rapoport Da, Persson GR. Treatment of intrabony defects with resorbable materials, non resorbable materials and flap debridement. J Clin. Periodontol 2000 Mar; 27(3):169-78.

Recebido para publicação: 19/03/2003

Encaminhado para reformulações: 20/05/2003

Pronto para publicação: 12/11/2003

Corresponding author:

Maria do Carmo Machado Guimarães SQS 310, BLOCO H, APTO.404 BRASÍLIA DF

CEP- 70363-080

Tel: $\quad 614430347$ - 6199638741

Email: m.guimaraes@mailcity.com 